\title{
Quantum Chemical Studies of Mononuclear Zinc Species of Hydration and Hydrolysis
}

\author{
Mengqiang Zhu and Gang Pan* \\ State Key Laboratory of Environmental Aquatic Chemistry, Research Center for Eco-environmental Sciences, \\ Chinese Academy of Sciences, 18 Shuangqing Road, Beijing 100085, China
}

Received: September 30, 2004; In Final Form: June 11, 2005

\begin{abstract}
Optimal geometries, charge distributions, bond analysis, changes of Gibbs free energy, entropies and enthalpies of hydration, and hydrolysis reactions for mononuclear species of $\mathrm{Zn}^{2+}$ including hydrated and hydrolysis complexes were investigated using quantum chemical calculations in the gas phase. Optimized geometrical structures showed that the stable hydrated and hydrolysis zinc species without outer-sphere water molecules were $\mathrm{Zn}\left(\mathrm{H}_{2} \mathrm{O}\right)_{6}{ }^{2+}, \mathrm{Zn}(\mathrm{OH})\left(\mathrm{H}_{2} \mathrm{O}\right)_{3}{ }^{+}, \mathrm{Zn}(\mathrm{OH})_{2}\left(\mathrm{H}_{2} \mathrm{O}\right)_{2}, \mathrm{Zn}(\mathrm{OH})_{3}{ }^{-}$, and $\mathrm{Zn}(\mathrm{OH})_{4}{ }^{2-}$. Results of NPA (Natural Population Analysis) indicated that the charge on the $\mathrm{Zn}$ atom of the hydrated ions decreased but the charge on the zinc atom of the hydrolysis species increased with the increase of inner-sphere water molecules. NBO (Natural Bond Orbital) analyses demonstrated that hydrated and hydrolysis species of zinc were mainly electrostatic bonding compounds. Calculations of reaction energies indicated that inner-sphere water molecules became more unfavorable as the hydrolysis increased. Stepwise hydrolysis equilibrium constants decreased successively and the order remained unchanged when the inner-sphere dehydration occurred.
\end{abstract}

\section{Introduction}

Interactions between metal ions and water, such as hydration and hydrolysis, play a fundamental role in regulating species, reactivity, and mobility of metal ions in an aquatic environment. Much progress has been made in measuring the adsorption mechanism of metal ions on mineral-water interfaces using synchrotron-based techniques such as EXAFS (Extended X-ray Absorption Fine Structure). ${ }^{1-5}$ However, current instrumental methods are still far from determining the microstructures and stoichiometry of different hydrated and hydrolysis species of metal ions, which greatly limits our understanding of their chemical, biological, and surface activities at the molecular level. Quantum chemical calculations are therefore an important tool for understanding the mechanisms of environmentally relevant chemical processes.

It is known that zinc ions in acid aquatic solutions are in the form of $\mathrm{Zn}\left(\mathrm{H}_{2} \mathrm{O}\right)_{6}{ }^{2+} \cdot{ }^{1-4}$ As the $\mathrm{pH}$ increases in dilute solutions, mononuclear hydroxide complexes of the form $\mathrm{Zn}(\mathrm{OH})_{n}\left(\mathrm{H}_{2} \mathrm{O}\right)_{m}{ }^{2-n}$ ( $n=1-4, m$ is not known) emerge. ${ }^{6}$ So far the microstructures of $\mathrm{Zn}\left(\mathrm{H}_{2} \mathrm{O}\right)_{6}{ }^{2+}$ and $\mathrm{Zn}(\mathrm{OH})_{4}{ }^{2+}$ have been measured by EXAFS. ${ }^{7}$ However, it is difficult to determine the microstructures of $\mathrm{Zn}(\mathrm{OH})_{n}\left(\mathrm{H}_{2} \mathrm{O}\right)_{m}{ }^{2-n}$, because the concentration of soluble $\mathrm{Zn}$ (II) at $\mathrm{pH}$ values of $8-13$, where these species exist, is too low to be detected by EXAFS. Also, different zinc species coexist simultaneously in this $\mathrm{pH}$ range, making the measurement of individual species difficult with EXAFS. Furthermore, the order of the experimentally measured stepwise hydrolysis equilibrium constants is often contradicted among different investigators due to various experimental limitations. ${ }^{6,8-13}$ Quantum chemical analysis could be helpful in improving our understandings of these problems.

Most of the theoretical studies in this field focus on hydrated ions, and only a little attention has been given to the corresponding hydrolysis species. ${ }^{14-20}$ In this study, we studied

* Address correspondence to this author. Phone: +86-10-62849686. Fax: +86-10-62923563. E-mail: gpan@mail.rcees.ac.cn. geometrical structures, charge distributions, and bond structures of hydrated and hydrolysis complexes of $\mathrm{Zn}^{2+}$, as well as the mechanisms of hydration, dehydration, and hydrolysis.

\section{Methods}

Full geometry optimizations and vibrational frequency analyses were performed without any symmetry constraints using density functional theory (DFT) in conjunction with the B3LYP hybrid functional with programs of the Gaussian 98 series. ${ }^{21}$ In this work, $\mathrm{Zn}{ }^{2+}$ has the $3 \mathrm{~d}^{10} \mathrm{~s}^{0}$ electron occupation which is favored by the DFT method. ${ }^{14}$ To maximize the possibility of finding the global minima, geometry optimizations were started from several different initial structures where water molecules and hydroxide ions were coordinated with $\mathrm{Zn}$ directly (i.e., only an inner-shell was included in the initial structures). Frequency analyses were used to confirm the local minima on the potential energy surface (PES) and to obtain $G^{\circ}{ }_{298}$ and $H^{\circ}{ }_{298}$ with thermal corrections. Spin restriction was adopted in all calculations and spin conservation was assumed in deprotonation reactions. The basis set was 6-311++g(3df) for zinc and 6-311++g(d,p) for $\mathrm{O}$ and $\mathrm{H}^{22}$ Additionally, $\mathrm{H}^{\circ}{ }_{298}$ calculations with the B3LYP thermal corrections and the natural population analysis (NPA) were carried out at RMP2/6-311+ $+\mathrm{g}(\mathrm{d}, \mathrm{f})$, and natural bond orbital analysis (NBO) at RHF/6-311++g(d,f) on the B3LYP optimal structures.

Following other authers, ${ }^{14,15}$ various species were optimized in the gas phase, although the method did not take outer-sphere water molecules into account, which is different from real aquatic systems.

\section{Results and Discussion}

3.1. Coordination Number. Optimal geometries are shown in Figure 1. Frequency analysis confirmed local minima on the potential energy surface for these structures. $\mathrm{Zn}(\mathrm{OH})_{n}\left(\mathrm{H}_{2} \mathrm{O}\right)_{m}{ }^{2-n}$. $v \mathrm{H}_{2} \mathrm{O}$ indicates that there were $m$ inner-sphere water molecules and $v$ outer-sphere water molecules. 


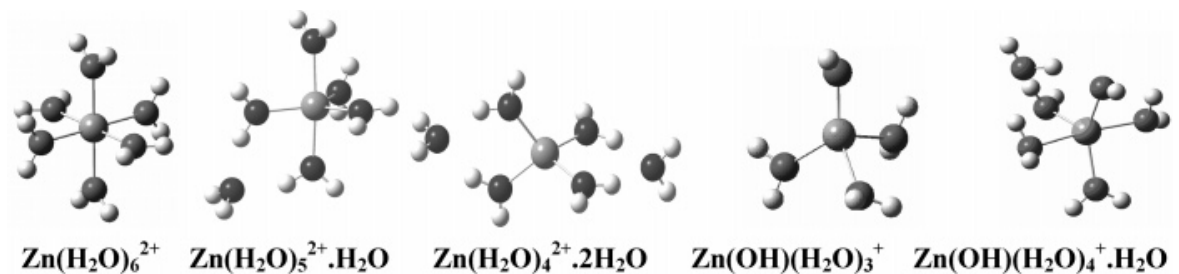

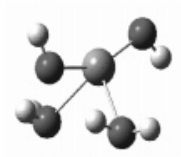

$\mathrm{Zn}(\mathrm{OH})_{2}\left(\mathrm{H}_{2} \mathrm{O}\right)_{2}$

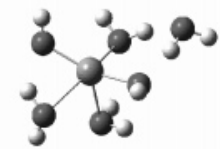

$\mathrm{Zn}(\mathrm{OH})_{2}\left(\mathrm{H}_{2} \mathrm{O}\right)_{3} \cdot \mathrm{H}_{2} \mathrm{O}$

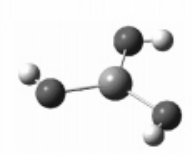

$\mathrm{Zn}(\mathrm{OH})_{3}{ }^{*}$

--- H

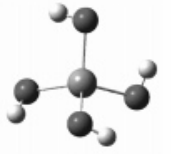

$\mathrm{Zn}(\mathrm{OH})_{4}{ }^{2-}$

Figure 1. Some calculated structures of hydrated and hydrolysis species of $\mathrm{Zn}$. MP2 energies for $\mathrm{Zn}\left(\mathrm{H}_{2} \mathrm{O}\right)_{6}{ }^{2+}, \mathrm{Zn}\left(\mathrm{H}_{2} \mathrm{O}\right)_{5}{ }^{2+} \cdot \mathrm{H}_{2} \mathrm{O}$, and $\mathrm{Zn}\left(\mathrm{H}_{2} \mathrm{O}\right)_{4}{ }^{2+}$. $2 \mathrm{H}_{2} \mathrm{O}$ were $-2235.313585,-2235.3114956$, and -2235.3115494 au, respectively.

TABLE 1: Optimal Geometrical Structures of Zn at the B3LYP(MP2/6-311++G(d,p) Level

\begin{tabular}{lclll}
\hline & $\mathrm{CN}^{a}$ & \multicolumn{1}{c}{$\mathrm{Zn}-\mathrm{OH}^{b}(\AA)$} & \multicolumn{1}{c}{$\mathrm{Zn}-\mathrm{OH}_{2}{ }^{c}(\AA)$} & \multicolumn{2}{c}{$\mathrm{Zn}-\mathrm{O}^{d}(\AA)$} \\
\hline $\mathrm{Zn}\left(\mathrm{H}_{2} \mathrm{O}\right)_{6}{ }^{2+}$ & 6 & & $2.123(2.112)$ & $2.123(2.112)$ \\
$\mathrm{Zn}(\mathrm{OH})\left(\mathrm{H}_{2} \mathrm{O}\right)_{3}{ }^{+}$ & 4 & $1.804(1.800)$ & $2.054(2.031), 2.100(2.095), 2.074(2.037)$ & $2.0089(1.991)$ \\
$\mathrm{Zn}(\mathrm{OH})_{2}\left(\mathrm{H}_{2} \mathrm{O}\right)_{2}$ & 4 & $1.889(1.873), 1.819(1.810)$ & $2.259(2.191) \times 2$ & $2.056(2.016)$ \\
$\mathrm{Zn}(\mathrm{OH})_{3}{ }^{-}$ & 3 & $1.904(1.872) \times 3$ & & $1.904(1.872)$ \\
$\mathrm{Zn}(\mathrm{OH})_{4}{ }^{2-}$ & 4 & $1.033(1.991) \times 4$ & & $2.033(1.991)$
\end{tabular}

${ }^{a}$ Inner-sphere coordination number. ${ }^{b}$ Distance between $\mathrm{Zn}$ and $\mathrm{O}$ of $\mathrm{OH}^{-}$in the inner-sphere. ${ }^{c}$ Distance between $\mathrm{Zn}$ and $\mathrm{O}$ of $\mathrm{H}_{2} \mathrm{O}$ in the inner-sphere. ${ }^{d}$ Average $\mathrm{Zn}-\mathrm{O}$ distance of the inner-sphere including $\mathrm{Zn}-\mathrm{OH}$ and $\mathrm{Zn}-\mathrm{OH}_{2}$.

For hydrated $\mathrm{Zn}^{2+}$, the optimal structure was $\mathrm{Zn}\left(\mathrm{H}_{2} \mathrm{O}\right)_{6}{ }^{2+}$ (Figure 1), which agreed well with other experimental ${ }^{1-4}$ and theoretical ${ }^{15}$ results. We also optimized at the B3LYP level and calculated the MP2 energies on the optimal structures of $\mathrm{Zn}$ $\left(\mathrm{H}_{2} \mathrm{O}\right)_{5}{ }^{2+} \cdot \mathrm{H}_{2} \mathrm{O}$ and $\mathrm{Zn}\left(\mathrm{H}_{2} \mathrm{O}\right)_{4}{ }^{2+} \cdot 2 \mathrm{H}_{2} \mathrm{O}$ (Figure 1). The MP2 energy difference $(\sim 5.5 \mathrm{~kJ} / \mathrm{mol})$ between them was bigger than that reported by Bock et al. ${ }^{23}$ at the MP2//RHF level.

The optimal structures of $\mathrm{Zn}(\mathrm{OH})\left(\mathrm{H}_{2} \mathrm{O}\right)_{5}{ }^{+}$and $\mathrm{Zn}(\mathrm{OH})_{2-}$ $\left(\mathrm{H}_{2} \mathrm{O}\right)_{4}$ with initial coordination number 6 were $\mathrm{Zn}(\mathrm{OH})\left(\mathrm{H}_{2} \mathrm{O}\right)_{4}{ }^{+}$. $\mathrm{H}_{2} \mathrm{O}$ and $\mathrm{Zn}(\mathrm{OH})_{2}\left(\mathrm{H}_{2} \mathrm{O}\right)_{3} \cdot \mathrm{H}_{2} \mathrm{O}$ (Figure 1), respectively. Removal of their outer-sphere water molecules yielded structures of $\mathrm{Zn}$ $(\mathrm{OH})\left(\mathrm{H}_{2} \mathrm{O}\right)_{3}{ }^{+} \cdot \mathrm{H}_{2} \mathrm{O}$ and $\mathrm{Zn}(\mathrm{OH})_{2}\left(\mathrm{H}_{2} \mathrm{O}\right)_{2} \cdot \mathrm{H}_{2} \mathrm{O}$. Re-optimizing $\mathrm{Zn}$ $(\mathrm{OH})\left(\mathrm{H}_{2} \mathrm{O}\right)_{3}{ }^{+} \cdot \mathrm{H}_{2} \mathrm{O}$ and $\mathrm{Zn}(\mathrm{OH})_{2}\left(\mathrm{H}_{2} \mathrm{O}\right)_{2} \cdot \mathrm{H}_{2} \mathrm{O}$ by removal of outer-sphere water molecules did not alter the coordination number. Bock et al. ${ }^{15}$ obtained $\mathrm{Zn}(\mathrm{OH})\left(\mathrm{H}_{2} \mathrm{O}\right)_{5} \cdot \mathrm{H}_{2} \mathrm{O}$ with RB3LYP/6-311++G(d,p), which was the same as our results. However, they also obtained a different structure of $\mathrm{Zn}(\mathrm{OH})$ $\left(\mathrm{H}_{2} \mathrm{O}\right)_{5}{ }^{+}$with coordination number 6 using RHF/HUZ*. We considered that the structure obtained by the B3LYP method was more accurate since it incorporated the effect of electron correlation, which was necessary for describing the transitional metal elements.

In the optimal structures of $\mathrm{Zn}(\mathrm{OH})_{3}\left(\mathrm{H}_{2} \mathrm{O}\right)_{3}{ }^{-}$and $\mathrm{Zn}(\mathrm{OH})_{4}{ }^{-}$ $\left(\mathrm{H}_{2} \mathrm{O}\right)_{2}{ }^{2-}$, all the water molecules migrated to the outer-sphere. For $\mathrm{Zn}(\mathrm{OH})_{3}{ }^{-}$and $\mathrm{Zn}(\mathrm{OH})_{4}{ }^{2-}$, optimal structures were planar trigonal and tetrahedron, respectively. The structure of $\mathrm{Zn}(\mathrm{OH})_{3}{ }^{-}$ was similar to that of solid $\mathrm{NaZn}(\mathrm{OH})_{3}$, where each zinc atom was present in a trigonal bipyramid of oxygen atoms and the three planar oxygen atoms were at $1.98 \AA$ and the other two at $2.65 \AA{ }^{6}$ The long distance of the axial oxygen atoms and the short distance of the planar oxygen atoms with $\mathrm{Zn}$ implied that the $\mathrm{Zn}^{2+}$ coordination number was 3 in solid $\mathrm{NaZn}(\mathrm{OH})_{3}$. The Raman spectrum of $\mathrm{Zn}(\mathrm{OH})_{4}{ }^{2-}$ observed in ref 6 was consistent with $T_{d}$ symmetry, whose structure was close to that of solid $\mathrm{Zn}(\mathrm{OH})_{2}$ where each zinc atom bound four hydroxide ions in the periphery.
Zinc ion compounds had a flexible coordination number of 4,5 , and 6 , which was different from other transitional metals whose coordination numbers were mainly $6 .^{23}$ Our results showed that, except for hydrated zinc ion, the coordination numbers of hydrolysis products were all less than 6 . However, a considerable number of metal ions could maintain a coordination number of 6 during the hydrolysis process, such as $\mathrm{Hg}^{2+}, 24$ $\mathrm{Mg}^{2+}, \mathrm{Mn}^{2+}$, and many trivalent metal ions. ${ }^{18,19}$ This might be the reason adsorbed zinc ions tend to dehydrate to the quadridentate complex compared with the adsorbed hydrated $\mathrm{Hg}^{2+},{ }^{24}$ $\mathrm{Cd}^{2+}, 25$ and $\mathrm{Co}^{2+26}$ ions on the mineral surface.

3.2. Bond Distance. The $\mathrm{Zn}-\mathrm{OH}_{2}$ distance of $\mathrm{Zn}\left(\mathrm{H}_{2} \mathrm{O}\right)_{6}{ }^{2+}$ in the literature was in the range of 2.05 to $2.14 \AA$ by theoretical calculations $^{15,23}$ and 2.07 to $2.18 \AA$ by experiments ${ }^{1-5}$ (Table 1). Our results, i.e., $2.123 \AA$ at the B13YP level and $2.112 \AA$ at the MP2 level, reasonably agreed with them. The calculated $\mathrm{Zn}-\mathrm{OH}$ distance in $\mathrm{Zn}(\mathrm{OH})_{4}{ }^{2-}$ was $2.033 \AA$, which was bigger than the measured value of $1.96 \AA$ by EXAFS. ${ }^{7}$ This was because the bond length calculated in vacuo was generally larger than that of measured values in solution due to the neglect of the outer-sphere water molecules. In addition, from Table 1, it can be seen that calculated values of bond length at the MP2 level were smaller than those at the B3LYP level.

The average inner-sphere $\mathrm{Zn}-\mathrm{O}$ distance increased remarkably with inner-sphere coordination number before its saturation (Figure 2). The average inner-sphere $\mathrm{Zn}-\mathrm{O}$ distances of hydrolysis species were smaller before coordination number 3 but greater after coordination number 3 than those of $\mathrm{Zn}\left(\mathrm{OH}_{2}\right)_{n}{ }^{2+}$ $(n=1-6)$. This was caused by increased repulsions in the series $\mathrm{H}_{2} \mathrm{O}-\mathrm{H}_{2} \mathrm{O}, \mathrm{OH}^{-}-\mathrm{H}_{2} \mathrm{O}$, and $\mathrm{OH}^{-}-\mathrm{OH}^{-}$.

There were hydrogen bonds between water $\mathrm{H}$ and hydroxide $\mathrm{O}$ in the inner-sphere of the $\mathrm{Zn}$ hydrolysis species. Compared with $\mathrm{Li}(\mathrm{OH})\left(\mathrm{H}_{2} \mathrm{O}\right)_{n}(n=1-4),{ }^{27}$ hydrogen bonds of the zinc hydrolysis species were weaker since $\mathrm{HOH}-\mathrm{-OH}$ distances $(1.830-2.833 \AA$ ) were bigger than those of Li (1.59-1.69 $\AA$ ) because the distances of $\mathrm{Zn}-\mathrm{OH}_{2}$ and $\mathrm{Zn}-\mathrm{OH}$ were bigger than 


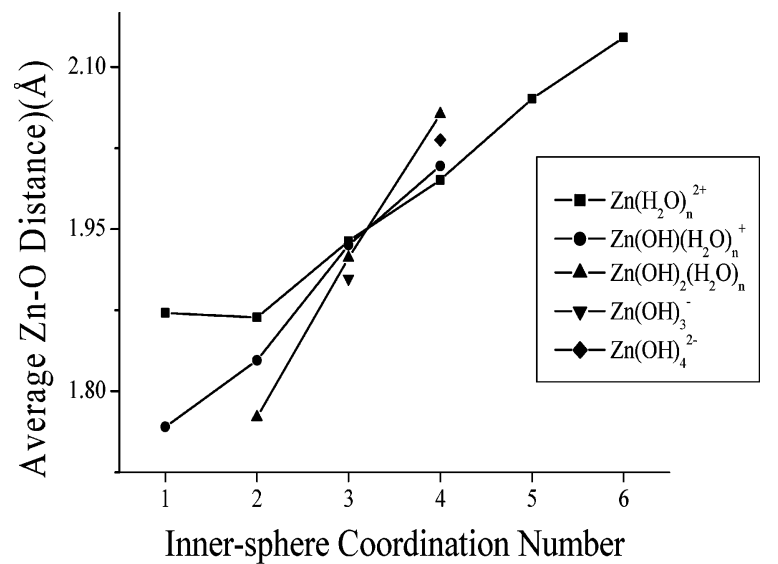

Figure 2. The average $\mathrm{Zn}-\mathrm{O}$ distance in the inner-sphere as a function of inner-sphere coordination number.

those of $\mathrm{Li}-\mathrm{OH}_{2}$ and $\mathrm{Li}-\mathrm{OH}$ although both ions have similar radii $\left(\mathrm{Zn}^{2+}, 0.60 \AA\right.$; $\left.\mathrm{Li}^{+}, 0.59 \AA\right)$. In addition, the outer-sphere water molecules could also provide $\mathrm{O}$ and $\mathrm{H}$ to form hydrogen bonds with water $\mathrm{H}$ or hydroxide $\mathrm{O}$ of the inner-sphere, whose distances were from 1.550 to $1.877 \AA$ indicating strong interactions.

3.3. Bond Analysis and Charge Distributions. Calculated NPA charges and results of NBO analysis were listed in Table 2. NBO analysis did not indicate the presence of a formal bond between $\mathrm{Zn}^{2+}$ and $\mathrm{O}-\mathrm{OH}^{-}$except for $\mathrm{Zn}(\mathrm{OH})\left(\mathrm{H}_{2} \mathrm{O}\right)_{n}{ }^{+}(n=$ $0-3)$ and $\mathrm{Zn}(\mathrm{OH})_{2}\left(\mathrm{H}_{2} \mathrm{O}\right)_{n}(n=0-2)$ (Table 2). The $\mathrm{Zn}-\mathrm{OH}$ bonds in $\mathrm{Zn}(\mathrm{OH})_{3}{ }^{-}$and $\mathrm{Zn}(\mathrm{OH})_{4}{ }^{2-}$ were electrostatic only because the $\mathrm{OH}^{-}-\mathrm{OH}^{-}$repulsions were much stronger ${ }^{14}$ than those in $\mathrm{Zn}(\mathrm{OH})\left(\mathrm{H}_{2} \mathrm{O}\right)_{n}{ }^{+}(n=0-3)$ and $\mathrm{Zn}(\mathrm{OH})_{2}\left(\mathrm{H}_{2} \mathrm{O}\right)_{n}(n=$ $0-2)$, which led to the expanded $\mathrm{Zn}-\mathrm{OH}$ distance and accordingly no covalent interaction. The electrostatic $\mathrm{Zn}-\mathrm{OH}_{2}$ bond of all molecules resulted from the weak cation-dipole interaction. It was therefore concluded that hydrated and hydrolysis species of zinc ions were mainly electrostatic bonding compounds.

Figure 3 showed that the charge of the $\mathrm{Zn}$ atom decreased with the increase of $\mathrm{H}_{2} \mathrm{O}$ for $\mathrm{Zn}\left(\mathrm{H}_{2} \mathrm{O}\right)_{n}{ }^{2+}(n=1-6)$ while it increased for hydrolysis species. This might be because the charge for the central $\mathrm{Zn}$ atom depends on the net effect of the central $\mathrm{Zn}$-ligand attraction and ligand-ligand repulsion for electrostatic bonding complexes. For $\mathrm{Zn}\left(\mathrm{H}_{2} \mathrm{O}\right)_{n}{ }^{2+}(n=1-6)$, $\mathrm{Zn}-\mathrm{OH}_{2}$ attraction overwhelmed $\mathrm{H}_{2} \mathrm{O}-\mathrm{H}_{2} \mathrm{O}$ repulsion, hence the $\mathrm{Zn}$ charge fell down with the increase of $\mathrm{H}_{2} \mathrm{O}$. But for the hydrolysis species, the situation was reverse. The opposite trend between hydrolysis and hydrated species resulted from the stronger repulsion of $\mathrm{OH}^{-}$to other ligands than that of $\mathrm{H}_{2} \mathrm{O}$.

For $\mathrm{Zn}(\mathrm{OH})_{n}{ }^{2-n}(n=1-4)$ without inner-sphere water molecules (doted line in Figure 3), the charge of $\mathrm{Zn}$ decreased first, then increased with the number of $\mathrm{OH}^{-}$. This was because $\mathrm{Zn}$-ligand attraction was dominant (partly covalent) for $\mathrm{Zn}(\mathrm{OH})^{+}$

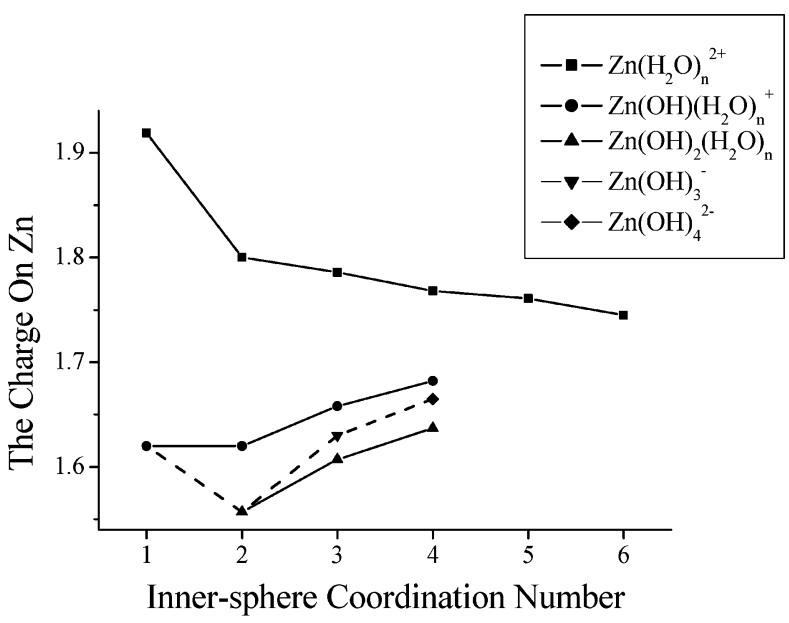

Figure 3. The charge of central $\mathrm{Zn}$ in hydrated and hydrolysis species.

and $\mathrm{Zn}(\mathrm{OH})_{2}$, so the $\mathrm{Zn}$ charge in $\mathrm{Zn}(\mathrm{OH})_{2}$ was less than that in $\mathrm{Zn}(\mathrm{OH})^{+}$. With the increase of $\mathrm{OH}^{-}$, the $\mathrm{Zn}$ charge increased successively from $\mathrm{Zn}(\mathrm{OH})_{2}$ to $\mathrm{Zn}(\mathrm{OH})_{3}{ }^{-}$to $\mathrm{Zn}(\mathrm{OH})_{4}{ }^{2-}$ since $\mathrm{OH}^{-}-\mathrm{OH}^{-}$repulsion became dominant and covalence disappeared.

3.4. Stepwise Hydration Reactions. Calculated energies of stepwise binding $\mathrm{H}_{2} \mathrm{O}$ for hydrated ions and hydroxide products were presented in Table 3 and Figure 4. Figure 4A showed that $\Delta G^{\circ}{ }_{298}$ of binding one water molecule increased successively in the order of $\mathrm{Zn}^{2+}, \mathrm{Zn}(\mathrm{OH})^{+}$, and $\mathrm{Zn}(\mathrm{OH})_{2}$, indicating that with the increase of hydroxide ions, i.e., with the increase of hydrolysis, binding water molecules became more difficult and more water molecules would dissociate from the inner-sphere. This was because the more $\mathrm{OH}^{-}$bound to $\mathrm{Zn}$, the greater repulsion to $\mathrm{H}_{2} \mathrm{O}$, which elevated the $\Delta G^{\circ}{ }_{298}$ of binding water and therefore made the binding of water molecules difficult. This result agreed with literature results. ${ }^{6,28}$ Additionally, in each species, the binding energies increased with the coordination number (Figure 4A) because of ligand repulsions.

3.5. Stepwise Hydrolysis Reactions. We used the protontransfer reaction to analyze the hydrolysis of zinc ions. Many investigators ${ }^{15,18,19}$ considered that there was no dehydration process in the first-order hydrolysis reaction for hydrated metal ions. However, our calculations indicated that dehydration processes happened during the hydrolysis reactions of zinc ions, especially for the high order hydrolysis. It was appropriate to symbolize hydrolysis reactions for divalent ions with the following equation:

$$
\begin{array}{r}
\mathrm{M}(\mathrm{OH})_{m}\left(\mathrm{H}_{2} \mathrm{O}\right)_{n}{ }^{(2-m)+}=\mathrm{M}(\mathrm{OH})_{(m+1)}\left(\mathrm{H}_{2} \mathrm{O}\right)_{(n-v-2)}{ }^{(1-m)}+ \\
\mathrm{H}_{3} \mathrm{O}^{+}+v \mathrm{H}_{2} \mathrm{O}
\end{array}
$$

From Figure 4B, the $\Delta G^{\circ}{ }_{298}$ of deprotonation for $\mathrm{Zn}\left(\mathrm{H}_{2} \mathrm{O}\right)_{n}{ }^{2+}$ $(n=1-6)$ and $\mathrm{Zn}(\mathrm{OH})\left(\mathrm{H}_{2} \mathrm{O}\right)_{n}{ }^{+}(n=1-3)$ increased remarkably

TABLE 2: NPA Charge $(C)$ on $\mathrm{Zn}, \mathrm{H}_{2} \mathrm{O}$, and $\mathrm{OH}^{-}$at the MP2 Level and NBO Results of the $\mathrm{Zn}-\mathrm{OH}$ Bond at the $\mathrm{HF}$ Level

\begin{tabular}{lcccccccrcr}
\hline \multicolumn{1}{c}{ species } & $Q_{\mathrm{Zn}}$ & $Q_{\mathrm{OH}}$ & $Q_{\mathrm{H} 2 \mathrm{O}}$ & $\mathrm{Zn}, \%^{a}$ & species & $Q_{\mathrm{Zn}}$ & $Q_{\mathrm{OH}}$ & $Q_{\mathrm{H} 2 \mathrm{O}}$ & $\mathrm{Zn}, \%^{a}$ \\
\hline $\mathrm{Zn}\left(\mathrm{H}_{2} \mathrm{O}\right)^{2+}$ & 1.919 & & 0.081 & & $\mathrm{Zn}(\mathrm{OH})\left(\mathrm{H}_{2} \mathrm{O}\right)_{2}{ }^{+}$ & 1.658 & -0.762 & 0.052 & 7.28 \\
$\mathrm{Zn}\left(\mathrm{H}_{2} \mathrm{O}\right)_{2}{ }^{2+}$ & 1.800 & & 0.100 & & $\mathrm{Zn}(\mathrm{OH})\left(\mathrm{H}_{2} \mathrm{O}\right)_{3}{ }^{+}$ & 1.682 & -0.812 & 0.043 & 5.83 \\
$\mathrm{Zn}\left(\mathrm{H}_{2} \mathrm{O}\right)_{3}{ }^{2+}$ & 1.786 & & 0.071 & & $\mathrm{Zn}(\mathrm{OH})_{2}$ & 1.557 & -0.779 & 7.56 \\
$\mathrm{Zn}\left(\mathrm{H}_{2} \mathrm{O}\right)_{4}{ }^{2+}$ & 1.768 & & 0.058 & & $\mathrm{Zn}(\mathrm{OH})_{2}\left(\mathrm{H}_{2} \mathrm{O}\right)$ & 1.607 & -0.812 & 0.017 & 6.71 \\
$\mathrm{Zn}\left(\mathrm{H}_{2} \mathrm{O}\right)_{5}{ }^{2+}$ & 1.761 & & 0.048 & & $\mathrm{Zn}(\mathrm{OH})_{2}\left(\mathrm{H}_{2} \mathrm{O}\right)_{2}$ & 1.637 & -0.837 & 0.018 & 5.93 \\
$\mathrm{Zn}\left(\mathrm{H}_{2} \mathrm{O}\right)_{6}{ }^{2+}$ & 1.745 & & 0.042 & & $\mathrm{Zn}(\mathrm{OH})_{3}{ }^{-}$ & 1.630 & -0.877 & 0.00 \\
$\mathrm{Zn}(\mathrm{OH})^{+}$ & 1.620 & -0.621 & & 10.96 & $\mathrm{Zn}(\mathrm{OH})_{4}{ }^{2-}$ & 1.665 & -0.917 & 0.00 \\
$\mathrm{Zn}(\mathrm{OH})\left(\mathrm{H}_{2} \mathrm{O}\right)^{+}$ & 1.620 & -0.698 & 0.078 & 10.29 & & &
\end{tabular}

${ }^{a}$ Contribution of $\mathrm{Zn}^{2+}$ to the $\mathrm{Zn}-\mathrm{OH}$ bond. 

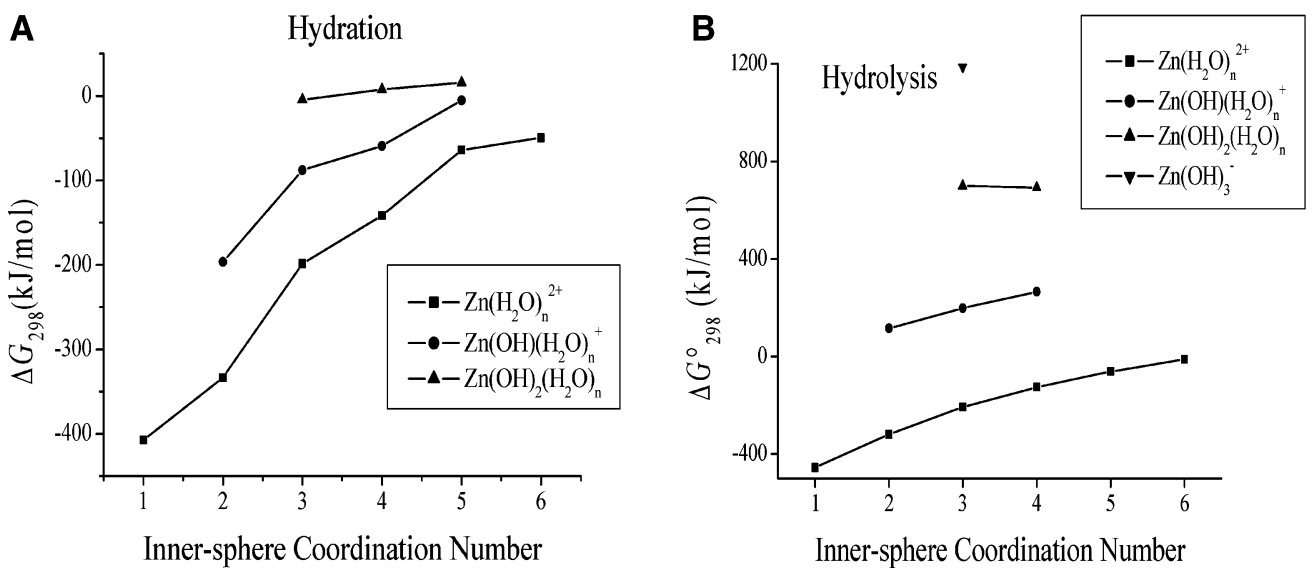

Figure 4. Calculated $\Delta G^{\circ}{ }_{298}$ for successive binding water reactions (A) and hydrolysis reactions (B) with a different number of water molecules in the inner-sphere.

TABLE 3: Calculated $\Delta G^{\circ}{ }_{298}$ and $\Delta H^{\circ}{ }_{298}(\mathrm{~kJ} / \mathrm{mol})$ of Successive Binding Waters at the B3LYP Level and $\Delta H^{\circ}{ }_{298}$ at the MP2 Level with Thermal Correction

\begin{tabular}{|c|c|c|c|}
\hline \multirow[b]{2}{*}{ hydration reactions } & \multicolumn{2}{|c|}{ B3LYP } & \multirow{2}{*}{$\begin{array}{l}\mathrm{MP} 2+ \\
\frac{\text { thermal correction }}{\Delta H_{298}^{\circ}}\end{array}$} \\
\hline & $\Delta G^{\circ}{ }_{298}$ & $\Delta H^{\circ}{ }_{298}$ & \\
\hline $\begin{array}{l}\mathrm{Zn}^{2+}+\mathrm{H}_{2} \mathrm{O}=\mathrm{Zn}\left(\mathrm{H}_{2} \mathrm{O}\right)^{2+} \\
\mathrm{Zn}\left(\mathrm{H}_{2} \mathrm{O}\right)^{2+}+\mathrm{H}_{2} \mathrm{O}=\mathrm{Zn}\left(\mathrm{H}_{2} \mathrm{O}\right)_{2}{ }^{2+} \\
\mathrm{Zn}\left(\mathrm{H}_{2} \mathrm{O}\right)_{2}{ }^{2+}+\mathrm{H}_{2} \mathrm{O}=\mathrm{Zn}\left(\mathrm{H}_{2} \mathrm{O}\right)_{3}{ }^{2+} \\
\mathrm{Zn}\left(\mathrm{H}_{2} \mathrm{O}\right)_{3}{ }^{2+}+\mathrm{H}_{2} \mathrm{O}=\mathrm{Zn}\left(\mathrm{H}_{2} \mathrm{O}\right)_{4}{ }^{2+} \\
\mathrm{Zn}\left(\mathrm{H}_{2} \mathrm{O}\right)_{4}{ }^{2+}+\mathrm{H}_{2} \mathrm{O}=\mathrm{Zn}\left(\mathrm{H}_{2} \mathrm{O}\right)_{5}{ }^{2+} \\
\mathrm{Zn}\left(\mathrm{H}_{2} \mathrm{O}\right)_{5}{ }^{2+}+\mathrm{H}_{2} \mathrm{O}=\mathrm{Zn}\left(\mathrm{H}_{2} \mathrm{O}\right)_{6}{ }^{2+}\end{array}$ & $\begin{array}{r}-407.7 \\
-333.7 \\
-198.6 \\
-141.7 \\
-63.9 \\
-49.8\end{array}$ & $\begin{array}{r}-435.8 \\
-370.8 \\
-234.5 \\
-179.0 \\
-106.4 \\
-98.5\end{array}$ & $\begin{array}{l}-414.3 \\
-363.3 \\
-241.8 \\
-189.9 \\
-118.3 \\
-112.7\end{array}$ \\
\hline $\begin{array}{l}\mathrm{Zn}(\mathrm{OH})^{+}+\mathrm{H}_{2} \mathrm{O}=\mathrm{Zn}(\mathrm{OH})\left(\mathrm{H}_{2} \mathrm{O}\right)^{+} \\
\mathrm{Zn}(\mathrm{OH})\left(\mathrm{H}_{2} \mathrm{O}\right)^{+}+\mathrm{H}_{2} \mathrm{O}=\mathrm{Zn}(\mathrm{OH})\left(\mathrm{H}_{2} \mathrm{O}\right)_{2}{ }^{+} \\
\mathrm{Zn}(\mathrm{OH})\left(\mathrm{H}_{2} \mathrm{O}\right)_{2}{ }^{+}+\mathrm{H}_{2} \mathrm{O}=\mathrm{Zn}(\mathrm{OH})\left(\mathrm{H}_{2} \mathrm{O}\right)_{3}{ }^{+} \\
\mathrm{Zn}(\mathrm{OH})\left(\mathrm{H}_{2} \mathrm{O}\right)_{3}{ }^{+} \cdot \mathrm{H}_{2} \mathrm{O}+\mathrm{H}_{2} \mathrm{O}=\mathrm{Zn}(\mathrm{OH})\left(\mathrm{H}_{2} \mathrm{O}\right)_{4}{ }^{+} \cdot \mathrm{H}_{2} \mathrm{O}\end{array}$ & $\begin{array}{r}-196.5 \\
-88.0 \\
-59.3 \\
-5.4\end{array}$ & $\begin{array}{r}-237.3 \\
-119.8 \\
-95.4 \\
-51.9\end{array}$ & $\begin{array}{r}-246.3 \\
-133.2 \\
-109.0 \\
-64.8\end{array}$ \\
\hline $\begin{array}{l}\mathrm{Zn}(\mathrm{OH})_{2}+\mathrm{H}_{2} \mathrm{O}=\mathrm{Zn}(\mathrm{OH})_{2}\left(\mathrm{H}_{2} \mathrm{O}\right) \\
\mathrm{Zn}(\mathrm{OH})_{2}\left(\mathrm{H}_{2} \mathrm{O}\right)+\mathrm{H}_{2} \mathrm{O}=\mathrm{Zn}(\mathrm{OH})_{2}\left(\mathrm{H}_{2} \mathrm{O}\right)_{2} \\
\mathrm{Zn}(\mathrm{OH})_{2}\left(\mathrm{H}_{2} \mathrm{O}\right)_{2} \cdot \mathrm{H}_{2} \mathrm{O}+\mathrm{H}_{2} \mathrm{O}=\mathrm{Zn}(\mathrm{OH})_{2}\left(\mathrm{H}_{2} \mathrm{O}\right)_{3} ? \mathrm{H}_{2} \mathrm{O}\end{array}$ & $\begin{array}{r}-4.7 \\
7.5 \\
15.7\end{array}$ & $\begin{array}{l}-42.3 \\
-31.9 \\
-23.5\end{array}$ & $\begin{array}{l}-49.6 \\
-41.3 \\
-32.3\end{array}$ \\
\hline
\end{tabular}

TABLE 4: Calculated $\Delta G^{\circ}{ }_{298}$ and $\Delta H^{\circ}{ }_{298}(\mathrm{~kJ} / \mathrm{mol})$ of the Stepwise Hydrolysis Reactions

\begin{tabular}{|c|c|c|c|}
\hline \multirow[b]{2}{*}{ hydrolysis reactions } & \multicolumn{2}{|c|}{ B3LYP } & \multirow{2}{*}{$\begin{array}{c}\text { MP2 }+ \\
\text { thermal correction } \\
\Delta H^{\circ}{ }_{298}\end{array}$} \\
\hline & $\Delta G^{\circ}{ }_{298}$ & $\Delta H^{\circ}{ }_{298}$ & \\
\hline \multicolumn{4}{|l|}{ first-order hydrolysis reaction } \\
\hline $\mathrm{Zn}^{2+}+2 \mathrm{H}_{2} \mathrm{O}=\mathrm{Zn}(\mathrm{OH})^{+}+\mathrm{H}_{3} \mathrm{O}^{+}$ & -863.3 & -890.5 & -848.3 \\
\hline $\mathrm{Zn}\left(\mathrm{H}_{2} \mathrm{O}\right)^{2+}+\mathrm{H}_{2} \mathrm{O}=\mathrm{Zn}(\mathrm{OH})^{+}+\mathrm{H}_{3} \mathrm{O}^{+}$ & -455.6 & -454.6 & -434.0 \\
\hline $\mathrm{Zn}\left(\mathrm{H}_{2} \mathrm{O}\right)_{2}{ }^{2+}+\mathrm{H}_{2} \mathrm{O}=\mathrm{Zn}(\mathrm{OH})\left(\mathrm{H}_{2} \mathrm{O}\right)^{+}+\mathrm{H}_{3} \mathrm{O}^{+}$ & -318.4 & -321.2 & -316.9 \\
\hline $\mathrm{Zn}\left(\mathrm{H}_{2} \mathrm{O}\right)_{3}^{2+}+\mathrm{H}_{2} \mathrm{O}=\mathrm{Zn}(\mathrm{OH})\left(\mathrm{H}_{2} \mathrm{O}\right)_{2}{ }^{+}+\mathrm{H}_{3} \mathrm{O}^{+}$ & -207.9 & -206.5 & -208.4 \\
\hline $\mathrm{Zn}\left(\mathrm{H}_{2} \mathrm{O}\right)_{4}^{2+}+\mathrm{H}_{2} \mathrm{O}=\mathrm{Zn}(\mathrm{OH})\left(\mathrm{H}_{2} \mathrm{O}\right)_{3}^{+}+\mathrm{H}_{3} \mathrm{O}^{+}$ & -125.5 & -122.9 & -127.5 \\
\hline $\mathrm{Zn}\left(\mathrm{H}_{2} \mathrm{O}\right)_{5}^{2+}=\mathrm{Zn}(\mathrm{OH})\left(\mathrm{H}_{2} \mathrm{O}\right)_{3}{ }^{+}+\mathrm{H}_{3} \mathrm{O}+$ & -61.6 & -16.4 & -9.2 \\
\hline $\mathrm{Zn}\left(\mathrm{H}_{2} \mathrm{O}\right)_{6}{ }^{2+}=\mathrm{Zn}(\mathrm{OH})\left(\mathrm{H}_{2} \mathrm{O}\right)_{3}{ }^{+}+\mathrm{H}_{2} \mathrm{O}+\mathrm{H}_{3} \mathrm{O}^{+}$ & -11.8 & 82.0 & 105.2 \\
\hline \multicolumn{4}{|l|}{ second-order hydrolysis reaction } \\
\hline $\mathrm{Zn}(\mathrm{OH})^{+}+2 \mathrm{H}_{2} \mathrm{O}=\mathrm{Zn}(\mathrm{OH})_{2}+\mathrm{H}_{3} \mathrm{O}^{+}$ & -81.9 & -119.7 & -136 \\
\hline $\mathrm{Zn}(\mathrm{OH})\left(\mathrm{H}_{2} \mathrm{O}\right)^{+}+\mathrm{H}_{2} \mathrm{O}=\mathrm{Zn}(\mathrm{OH})_{2}+\mathrm{H}_{3} \mathrm{O}^{+}$ & 114.6 & 117.7 & 109.4 \\
\hline $\mathrm{Zn}(\mathrm{OH})\left(\mathrm{H}_{2} \mathrm{O}\right)_{2}^{+}+\mathrm{H}_{2} \mathrm{O}=\mathrm{Zn}(\mathrm{OH})_{2}\left(\mathrm{H}_{2} \mathrm{O}\right)+\mathrm{H}_{3} \mathrm{O}^{+}$ & 197.9 & 195.2 & 193.1 \\
\hline $\mathrm{Zn}(\mathrm{OH})(\mathrm{H} 2 \mathrm{O})_{3}{ }^{+}+\mathrm{H}_{2} \mathrm{O}=\mathrm{Zn}(\mathrm{OH})_{2}\left(\mathrm{H}_{2} \mathrm{O}\right)_{2}+\mathrm{H}_{3} \mathrm{O}^{+}$ & 264.8 & 258.7 & 260.8 \\
\hline \multicolumn{4}{|l|}{ third-order hydrolysis reaction } \\
\hline $\mathrm{Zn}(\mathrm{OH})_{2}+2 \mathrm{H}_{2} \mathrm{O}=\mathrm{Zn}(\mathrm{OH})_{3}+\mathrm{H}_{3} \mathrm{O}^{+}$ & 695.3 & 658.3 & 643.5 \\
\hline $\mathrm{Zn}(\mathrm{OH})_{2}\left(\mathrm{H}_{2} \mathrm{O}\right)+\mathrm{H}_{2} \mathrm{O}=\mathrm{Zn}(\mathrm{OH})_{3}{ }^{-}+\mathrm{H}_{3} \mathrm{O}^{+}$ & 700.0 & 700.7 & 693.1 \\
\hline $\mathrm{Zn}(\mathrm{OH})_{2}\left(\mathrm{H}_{2} \mathrm{O}\right)_{2}=\mathrm{Zn}(\mathrm{OH})_{3}^{-}+\mathrm{H}_{3} \mathrm{O}^{+}$ & 692.5 & 732.5 & 734.4 \\
\hline \multicolumn{4}{|l|}{ fourth-order hydrolysis reaction } \\
\hline $\mathrm{Zn}(\mathrm{OH})_{3}{ }^{-}+2 \mathrm{H}_{2} \mathrm{O}=\mathrm{Zn}(\mathrm{OH})_{4}{ }^{2-}+\mathrm{H}_{3} \mathrm{O}^{+}$ & 1188.6 & 1152.4 & 1141.0 \\
\hline
\end{tabular}

with the increase of the inner-sphere water molecules, but those of $\mathrm{Zn}(\mathrm{OH})_{2}\left(\mathrm{H}_{2} \mathrm{O}\right)_{n}(n=1-2)$ decreased faintly (Figure $\left.4 \mathrm{~B}\right)$. This showed that inner-sphere waters made hydrolysis difficult for $\mathrm{Zn}\left(\mathrm{H}_{2} \mathrm{O}\right)_{n}{ }^{2+}$ and $\mathrm{Zn}(\mathrm{OH})\left(\mathrm{H}_{2} \mathrm{O}\right)_{n}{ }^{+}$, and easy for $\mathrm{Zn}(\mathrm{OH})_{2}{ }^{-}$ $\left(\mathrm{H}_{2} \mathrm{O}\right)_{n}$. This difference resulted from the positive $\Delta G^{\circ}{ }_{298}$ values of the binding water molecule for $\mathrm{Zn}(\mathrm{OH})_{2}\left(\mathrm{H}_{2} \mathrm{O}\right)$. It can be seen from Figure 4B that the stepwise hydrolysis constants decreased successively although the absolute values of calculated energies (Table 4) significantly deviated from experimental values due to the assumption of the gas phase and the inherent inaccuracy of this method on reaction energy calculations.

3.6. Dehydration Effect on the Hydrolysis Reactions. Generally, measured stepwise hydrolysis constants should decrease successively for most metal ions. Our results confirmed 
TABLE 5: Calculated $\Delta G^{\circ}{ }_{298}, \Delta H^{\circ}{ }_{298}$, and $\Delta S^{\circ}{ }_{298}(\mathrm{~kJ} / \mathrm{mol})$ for Hydrolysis When a Different Number of Water Molecules Dehydrated $^{a}$

\begin{tabular}{|c|c|c|c|}
\hline & $\Delta G^{\circ}{ }_{298}$ & $\Delta H^{\circ}{ }_{298}$ & $T \Delta S^{\circ}{ }_{298}$ \\
\hline $\mathrm{Zn}\left(\mathrm{H}_{2} \mathrm{O}\right)_{6}{ }^{+}=\mathrm{Zn}(\mathrm{OH})\left(\mathrm{H}_{2} \mathrm{O}\right)_{3}{ }^{+}+\mathrm{H}_{3} \mathrm{O}^{+}+\mathrm{H}_{2} \mathrm{O}$ & -11.8 & 82.0 & 93.8 \\
\hline $\mathrm{Zn}\left(\mathrm{H}_{2} \mathrm{O}\right)_{6}{ }^{+}=\mathrm{Zn}(\mathrm{OH})\left(\mathrm{H}_{2} \mathrm{O}\right)_{2}{ }^{+}+\mathrm{H}_{3} \mathrm{O}^{+}+2 \mathrm{H}_{2} \mathrm{O}$ & 47.5 & 177.4 & 129.9 \\
\hline $\mathrm{Zn}\left(\mathrm{H}_{2} \mathrm{O}\right)_{6}^{+}=\mathrm{Zn}(\mathrm{OH})\left(\mathrm{H}_{2} \mathrm{O}\right)++\mathrm{H}_{3} \mathrm{O}^{+}+3 \mathrm{H}_{2} \mathrm{O}$ & 135.6 & 297.2 & 161.7 \\
\hline $\mathrm{Zn}\left(\mathrm{H}_{2} \mathrm{O}\right)_{6}{ }^{2+}=\mathrm{Zn}(\mathrm{OH})++\mathrm{H}_{3} \mathrm{O}^{+}+4 \mathrm{H}_{2} \mathrm{O}$ & 332.1 & 534.5 & 202.4 \\
\hline $\mathrm{Zn}(\mathrm{OH})\left(\mathrm{H}_{2} \mathrm{O}\right)_{3}{ }^{+}+\mathrm{H}_{2} \mathrm{O}=\mathrm{Zn}(\mathrm{OH})_{2}\left(\mathrm{H}_{2} \mathrm{O}\right)_{2}+\mathrm{H}_{3} \mathrm{O}^{+}$ & 264.8 & 258.7 & -6.1 \\
\hline $\mathrm{Zn}(\mathrm{OH})\left(\mathrm{H}_{2} \mathrm{O}\right)_{3}{ }^{+}=\mathrm{Zn}(\mathrm{OH})_{2}\left(\mathrm{H}_{2} \mathrm{O}\right)+\mathrm{H}_{3} \mathrm{O}^{+}$ & 257.2 & 290.5 & 33.3 \\
\hline $\mathrm{Zn}(\mathrm{OH})\left(\mathrm{H}_{2} \mathrm{O}\right)_{3}{ }^{+}=\mathrm{Zn}(\mathrm{OH})_{2}+\mathrm{H}_{3} \mathrm{O}^{+}+\mathrm{H}_{2} \mathrm{O}$ & 262.0 & 332.8 & 70.9 \\
\hline $\mathrm{Zn}(\mathrm{OH})_{2}\left(\mathrm{H}_{2} \mathrm{O}\right)_{2}=\mathrm{Zn}(\mathrm{OH})_{3}^{-}+\mathrm{H}_{3} \mathrm{O}^{+}$ & 662.2 & 670.4 & 8.1 \\
\hline
\end{tabular}

this rule. However, in experiments, many investigators measured that $K_{2}$ was greater than $K_{1}$ or $K_{3}$ greater than $K_{2}$ for $\mathrm{Zn}$. $^{6,8-13}$ Bochatay and Persson ${ }^{3}$ explained that it was the dehydration of the inner-sphere that increased the hydrolysis constants. Dehydration processes would result in the increase of entropy and reduce $\Delta G^{\circ} 298$ accordingly, i.e., increase hydrolysis constants. Baes and Mesmer ${ }^{6}$ thought that the bias might come from the experimental limitation that the solubility of $\mathrm{Zn}(\mathrm{OH})_{2}$ and $\mathrm{ZnO}$ as a function of $\mathrm{pH}$ could not be determined accurately. To investigate the effect of dehydration entropy change on the hydrolysis reactions, $\Delta G^{\circ}{ }_{298}$ values of the hydrolysis reactions with different dissociated water molecules were calculated. Table 5 showed that $\Delta G^{\circ}{ }_{298}, \Delta H^{\circ}{ }_{298}$, and $T \Delta S^{\circ}{ }_{298}$ of the first-order hydrolysis reactions all increased with the increase of water molecules dissociated. This meant that $\Delta G^{\circ}{ }_{298}$ was controlled by $\Delta H^{\circ}{ }_{298}$, and entropy change at $298.15 \mathrm{~K}$ induced by dehydration of the inner-sphere could not make $\Delta G^{\circ}{ }_{298}$ decrease. For the second-order hydrolysis, the corresponding $\Delta G^{\circ}{ }_{298}$ decreased from $264.75 \mathrm{~kJ} / \mathrm{mol}$ to $257.23 \mathrm{~kJ} / \mathrm{mol}$ while $\Delta S^{\circ}{ }_{298}$ increased from $-0.020 \mathrm{~kJ} / \mathrm{mol} \cdot \mathbf{k}$ to $0.112 \mathrm{~kJ} / \mathrm{mol} \cdot \mathbf{k}$. The decrease of $\Delta G^{\circ}{ }_{298}$ was too little to make the second hydrolysis constant smaller than the $K_{3}$ or greater than $K_{1}$. This analysis proved that dehydration could not change the sequence of the hydrolysis constants.

\section{Concluding Remarks}

There were significant differences between hydrated and hydrolysis complexes in charge distributions, bond types, reaction energies of hydration and hydrolysis due to the fact that $\mathrm{OH}^{-}$had a stronger repulsion to $\mathrm{OH}^{-}$and $\mathrm{H}_{2} \mathrm{O}$ and attraction to zinc. The deprotonation of a water molecule from $\mathrm{Zn}\left(\mathrm{H}_{2} \mathrm{O}\right)_{6}{ }^{2+}$ resulted in the collapse of the octahedral structure, and all the hydrolysis species had a coordination number of less than 6. All the zinc species in this study were electrical compounds where the ligand $\mathrm{H}_{2} \mathrm{O}$ imposed opposite effects on the charge of zinc for the hydrated and hydrolysis species. Hydration and hydrolysis processes restrained each other. The stepwise hydrolysis constants decreased successively without significant influence from the dehydration.

Acknowledgment. G.P. thanks the support of Chinese NNSF grant 20777050 and "the distinguished hundred scientists" program of the Chinese Academy of Sciences. We thank the Supercomputing Center of the Computer Network Information Center, Chinese Academy of Sciences for supplying computational facilities and programs. We thank valuable comments from an anonymous referee.

\section{References and Notes}

(1) Pan, G.; Qin, Y.; Li, X.; Hu, T.; Wu, Z.; Xie, Y. J. Colloid Interface Sci. 2004, 271, 28.

(2) Li, X.; Pan, G.; Qin, Y.; Hu, T.; Wu, Z.; Xie, Y. J. Colloid Interface Sci. 2004, 271, 35 .

(3) Bochatay, L.; Persson, P. J. Colloid Interface Sci. 2000, 229, 593.

(4) Li, X.; Pan, G.; Qin, Y.; Hu, T.; Wu, Z.; Xie, Y.; Chen, H.; Du, Y. High Energy Phys. Nucl. Phys. 2003, 27 (suppl), 23.

(5) Zhu, M.; Pan, G.; Li, X.; Liu, T.; Yang, Y.; Li, W.; Li, J. Acta Physico-Chimica Sinica. In press.

(6) Baes, C. F.; Mesmer, R. E. The Hydrolysis of Cations; John Wiley \& Sons: New York, 1976.

(7) Li, X.; Pan, G.; Zhu, M.; Hu, T.; Wu, Z.; Xie, Y. Nucl. Tech. 2004, 27,895 .

(8) Khodakovskiy, I. L.; Yelkin, A. Geokhimiya 1975, 10, 1490

(9) Ziemniak, S. E.; Jones, M. E.; Combs, K. E. S. J. Solution Chem. 1992, 21, 1153

(10) Hanzawa, Y.; Hiroishi, D.; Matsuura, C.; Ishigure, K.; Nagao, M.; Haginuma, M. Nucl. Sci. Eng. 1997, 127, 292.

(11) Shock, E. L.; Sassani, D. C.; Willis, M.; Sverjensky, D. A. Geochim. Cosmochim. Acta 1997, 61, 907.

(12) Bénézeth, P.; Palmer, D. A.; Wesolowski, D. J. Geochim. Cosmochim. Acta 1999, 63, 1571.

(13) Bénézeth, P.; Palmer, D. A.; Wesolowski, D. J.; Xiao, C. J. Solution Chem. 2002, 31.

(14) Ricca, A.; Bauschlicher, C. W. J. Phys. Chem. 1995, 99, 9003.

(15) Bock, C. W.; Katz, A. K.; Markham, G. D.; Glusker, J. P. J. Am. Chem. Soc. 1999, 121, 7360 .

(16) Rode, B. M.; Schwenk, C. F.; Tongraar, A. J. Mol. Liq. 2004, 10, 105.

(17) Kallies, B.; Meier, R. Inorg. Chem. 2001, 40, 3101.

(18) Pershina, V.; Kratz, J. V. Inorg. Chem. 2001, 40, 776.

(19) Rosso, K. M.; Rustad, J. R.; Gibbs, G. V. J. Phys. Chem. A. 2002, 106, 8133.

(20) Chang, C. M.; Jalbout, A. F.; Wang, M. K.; Lin, C. THEOCHEM 2003, 664-665, 21.

(21) Frisch, M. J.; Trucks, G. W.; Schlegel, H. B.; Scuseria, G. E.; Robb, M. A.; Cheeseman, J. R.; Zakrzewski, V. G.; Montgomery, J. A., Jr.; Stratmann, R. E.; Burant, J. C.; Dapprich, S.; Millam, J. M.; Daniels, A. D.; Kudin, K. N.; Strain, M. C.; Farkas, O.; Tomasi, J.; Barone, V.; Cossi, M.; Cammi, R.; Mennucci, B.; Pomelli, C.; Adamo, C.; Clifford, S.; Ochterski, J.; Petersson, G. A.; Ayala, P. Y.; Cui, Q.; Morokuma, K.; Malick, D. K.; Rabuck, A. D.; Raghavachari, K.; Foresman, J. B.; Cioslowski, J.; Ortiz, J. V.; Stefanov, B. B.; Liu, G.; Liashenko, A.; Piskorz, P.; Komaromi, I.; Gomperts, R.; Martin, R. L.; Fox, D. J.; Keith, T.; Al-Laham, M. A.; Peng, C. Y.; Nanayakkara, A.; Gonzalez, C.; Challacombe, M.; Gill, P. M. W.; Johnson, B. G.; Chen, W.; Wong, M. W.; Andres, J. L.; Head-Gordon, M.; Replogle, E. S.; Pople, J. A. Gaussian 98, revision A.11.3; Gaussian, Inc.: Pittsburgh, PA, 1998

(22) Foresman, J. B.; Frisch, A. Exploring Chemistry with Electronic Structrue Methods, 2nd ed.; Gaussian, Inc.: Pittsburgh, PA, 1996; p 100.

(23) Bock, C. W.; Katz, A. K.; Glusker, J. P. J. Am. Chem. Soc. 1995, 117,3754

(24) Collins, C. R.; Sherman, D. M.; Ragnarsdottir, K. V. J. Colloid Interface Sci. 1999, 219, 345

(25) Bochatay, L.; Persson, P. J. Colloid Interface Sci. 2000, 229, 584

(26) Towle, S. N.; Bargar, J. R.; Brown, G. E., Jr.; Parks, G. A. J. Colloid Interface Sci. 1999, 217,312

(27) Marshall, C. L.; Nicholas, J. B.; Brand, H.; Carrado, K. A.; Winans, R. E. J. Phys. Chem. 1996, 100, 15748.

(28) Nordin, J. P.; Sullivan, D. J.; Phillips, B. L.; Casey, W. H. Inorg. Chem. 1998, 37, 4760 . 